\title{
Perspectives on the Early Quality of Evidence Guiding the Therapeutic Management of SARS CoV-2: A Systematic Literature Review
}

Kaushik Subramanian

Indegene Pvt Ltd, Bengaluru, India

Anuradha Nalli

Indegene Pvt Ltd, Bengaluru, India

Vinitha Senthil

Indegene Pvt Ltd, Bengaluru, India

Saurabh Jain

Indegene Pvt Ltd, Bengaluru, India

Aravind Nayak

Indegene Pvt Ltd, Bengaluru, India

Amit Bhat ( $\square$ amit.bhat@indegene.com )

Indegene Pvt Ltd, Shanghai, China

\section{Systematic Review}

Keywords: clinical cure, evidence, SARS-CoV-2, treatment options, virological cure

Posted Date: July 7th, 2020

DOI: https://doi.org/10.21203/rs.3.rs-40221/v1

License: @ (i) This work is licensed under a Creative Commons Attribution 4.0 International License. Read Full License

Version of Record: A version of this preprint was published at Advances in Therapy on August 18th, 2020. See the published version at https://doi.org/10.1007/s12325-020-01460-5. 


\section{Abstract}

\section{Background:}

Severe acute respiratory syndrome coronavirus 2 (SARS-CoV-2) outbreak is a serious health concern. Repurposing of existing drugs indicated for other conditions seems to be the first choice for immediate therapeutic management. The quality of early evidence favoring the different treatment options needs to be apprised for informed decision making.

\section{Methods:}

In this systematic literature review, we apprised the quality of available evidence for different therapeutic options and also the basis for different treatment guidelines. In order to include all studies that are in different stages of publications, we also included studies from the preprint servers, BioRxiv, MedRxiv and published studies from PubMed.

\section{Results:}

We retrieved 5621 articles and included 20 studies for the systematic review. Based on our study, chloroquine/hydroxychloroquine either alone or in combination with azithromycin, remdesivir, corticosteroids, convalescent sera, ritonavir/lopinavir and arbidol were evaluated as therapeutic options. The data from different study designs reveal contradictory findings except for convalescent sera for which the evidence available is only from case series. Based on these early evidence, various national guidelines recommend remdesivir, convalescent sera, corticosteroids, hydroxychloroquine in different sub set of patients.

\section{Conclusion:}

Establishing consensus with respect to the endpoints to be assessed for respiratory viruses may enhance the quality of evidences in case of future pandemics. Further clinical evidence from the ongoing trials may lead to evolution of treatment guidelines with the addition of more therapeutic options.

\section{Introduction}

The severe acute respiratory syndrome coronavirus 2 (SARS-CoV-2) outbreak, which started off as a cluster of pneumonia cases in Wuhan, China, in December 2019, was declared as a pandemic by the World Health Organization (WHO) on March 11, 2020 [1]. As per the data from the WHO, as of May 31, 2020, it had infected 5.9 million people globally, with approximately $3,67,000$ people succumbing to the infection [2]. After isolation and sequence analysis, the causative virus was grouped into the coronavirus (CoV) family, consisting of RNA viruses that had already caused 2 different outbreaks of pneumonia in this decade. The severe acute respiratory syndrome (SARS) that broke out in 2003 was caused by SARS-CoV, whereas the middle-east respiratory syndrome (MERS) that broke out in 2012 was caused by the MERS-CoV [3]. The viral etiological agent was named as SARS-CoV-2 by the international viral classification commission, and the disease was officially named as COVID-19 by the WHO [4].

Clinical observation with SARS-CoV-2 revealed mild illness in majority of the patients and severe lung injury or multiorgan failure in approximately $5 \%$ of the patients, with a case fatality ratio of $1.4 \%$ [5]. The pathological findings in severely or critically ill patients revealed manifestations of shock and sepsis, which is hypothesized to be caused by the virus-induced "cytokine storm" [6]. The levels of proinflammatory cytokines and chemokines, including tumor necrosis factor (TNF)-a, interleukin (IL) - 1 $\beta$, IL -6 , granulocyte-colony-stimulating factor, interferon-gamma-induced protein-10, monocyte chemoattractant protein-1, and macrophage inflammatory proteins 1 -a, were reported to be elevated from early clinical observations, substantiating the "cytokine storm" hypothesis. In cases with mild infection, the resident macrophages in the lung initiate an inflammatory response culminating in the successful containment of the replication of SARS-CoV-2. However, in patients with severe COVID-19 infection, the pathological findings revealed the impairment of the epithelial-endothelial barrier, leading to a large exudate into the alveolar cavity [6]. The disruption of endothelial lining initiates a vicious cycle of tissue damage due to the inflammatory response facilitated by the accumulation of regional macrophages, neutrophils, and lymphocytes, resulting in "cytokine storm." Subsequent multiorgan failure because of direct viral replication in other organs and the systemic "cytokine storm" lead to hypoxemic respiratory failure, acute respiratory distress syndrome, and sepsis $(4,7)$.

Elderly patients and patients with comorbidities are more susceptible to severe COVID-19 infection [8]. The current case fatality of COVID-19 is lower than the 1918 influenza pandemic but higher than 1957 influenza pandemic [9]. But among the recent outbreaks of CoV infections (SARS-CoV and MERV), SARSCoV-2 was found to be much more adoptable to different geographic location with a higher propensity for person-person transfer [10].

The typical response to a pandemic involves both short-term and long-term plans to minimize case fatality and reduce response time for future pandemics [10]. The current strategies for reducing fatality mainly involves symptomatic management and therapeutic interventions [11]. The choices available for the therapeutic management were mainly based on immune modulators acting on inflammatory tissue damage and antiviral drugs. Although immune modulators can minimize the inflammatory effects, they may suppress the innate immune responses, leading to delay in viral clearance [10]. Antiviral drugs that were proven to be effective in the treatment of RNA virus infection were currently being explored as possible treatment options. But, in the era of evidencebased medicine, the response to a pandemic typically involves repurposing existing drugs targeting specific steps in the pathogenesis. The early evidence base for the successful treatment of COVID-19 may provide insights into mounting a response for future pandemics. Further, the gaps and drawbacks in the early evidences may also provide insights on mounting appropriate responses with respect to generation of clinical evidences in case of future pandemics. Unlike, previous pandemics, the current pandemic is in the era of evidence-based medicine wherein the responses by various national and international nodal organizations would be based only on the quality of evidence. Hence, in this present study, we evaluated the quality of early clinical evidence currently guiding 
the treatment strategies for COVID-19 and the formulation of different treatment guidelines. We also provided a perspective on the early quality evidence and its probable utility for futures responses to pandemics.

\section{Methods}

This systematic literature review aimed to answer the following questions: What are the different pharmacological interventions used in the therapeutic management of patients with COVID-19 infection? What is the quality of the evidence on which the different pharmacological interventions currently practiced in clinical settings for the therapeutic management of COVID-19 are based? Which drug/pharmacological interventions used for the therapeutic management of patients with COVID-19 have sufficient evidence to support their use in clinical practice?

\section{Data Sources and Searches}

In order to ensure the retrieval of all relevant studies, we searched PubMed with a broad key word "COVID-19." We also included COVID-19 studies in preprint servers, such as MedRxiv and BioRxiv. Duplicate studies were removed, and a consolidated excel sheet was prepared for screening. Any study evaluating a therapeutic drug in in vivo or in vitro model was considered as relevant evidence base and graded based on the hierarchy of evidence-based pyramid into preclinical, case report, case series, cross-sectional, retrospective cohort, prospective cohort, randomized controlled trials (RCTs), meta-analysis, and systematic reviews. This systematic literature review was registered in Prospero (CRD42020180148).

\section{Study Selection}

The systematic review yielded a total of 4027 articles from PubMed and 1591 articles from preprint servers (Figure 1).. Primary screening with the title and abstract revealed a total of 569 relevant articles. On the basis of the full-text screening, a total of 22 studies were included for the evidence synthesis. The studies included for appraisal ranged from case reports to RCTs.

\section{Data Extraction and Quality Assessment}

The evidences were categorized as very low, low, moderate, and strong as per the GRADE evidence profile (Table 2).. As per the GRADE system, evidence from RCTs was considered to be strong evidence, which is down-rated if there are serious limitations, imprecision, inconsistency, indirectness, or publication bias. Observational studies are rated as low quality and up-rated if the magnitude of the effect is large, minimal confounders and if there is a dose-dependent effect [12].

\section{Data Synthesis and Analysis}

The evidence base was individually rated for different end points within a single study. Studies synthesizing previous evidence base along with the expert opinions were also considered as an evidence base. The efficacy end points considered in preclinical studies included reduction in viral copy numbers evaluated by real-time polymerase chain reaction (RT-PCR) and lack of viral nucleoprotein assessed by immunofluorescence. However, in case of clinical studies, the various end points of efficacy assessed were either clinical cure (time to body temperature normalization, duration of cough, death, or clinical worsening of disease) or virological cure (negative RT-PCR).

\section{Result}

\section{Pharmacological Interventions}

On the basis of the systematic review of published evidence, the different pharmacological interventions explored for the therapeutic management of patients with COVID-19 were chloroquine/hydroxychloroquine, remdesivir, arbidol, lopinavir, ritonavir, glucocorticoids, immune modulators, immunoglobulin/plasma therapy, tissue plasminogen activator, recombinant erythropoietin, tocilizumab, baricitinib, ivermectin, tetracyclines, statins, homoharringtonine, and metronidazole. All the drugs that have been explored as therapeutic options were previously used for the treatment of other clinical conditions. Hence, the evidence base does not follow the conventional preclinical-early clinical (phases I and II)-phase III studies. But, on the contrary, the drugs are repurposed and the main aims of later-stage clinical trials are to reposition the drug for COVID-19 (repositioning clinical trials) [13].

\section{Chloroquine and Hydroxychloroquine:}

Chloroquine is a 9-aminoquinoline, which is a weak base and facilitates antimicrobial effect by increasing the pH of acidic vesicles. It has been safely used for the treatment of malaria, amoebiasis, Human Immune Virus, and autoimmune diseases [14]. The first evidence of its activity against CoV was provided by Vincent et al. in Vero E6 cells against SARS-CoV. They confirmed the prophylactic effect of chloroquine in Vero E6 cells that were pretreated with $10 \mu \mathrm{M}$ of chloroquine, which reduced the infectivity by $100 \%$ in comparison with the control. Similarly, the addition of 0.1 to $1 \mu \mathrm{M}$ of chloroquine after infection reduced the infection by $50 \%$, suggesting the probable therapeutic effect of chloroquine in SARS-CoV infection [14]. The anti-SARS-CoV-2 activity of chloroquine was assessed by Wang et al. in Vero E6 cell line. The time-of-addition assay suggested a probable role of chloroquine at the entry and post-entry stages of SARSCoV-2 infection. The effective concentration $\left(E_{90}\right.$ ) was found to be $6.90 \mu \mathrm{M}$, which is clinically achievable with the administration of 500 -mg chloroquine 
[15]. In further physiologically based pharmacokineticmodeling studies, hydroxychloroquine, which is an analog of chloroquine, was found to be more potent than chloroquine with better safety profile [16].

The first clinical evidence of efficacy was reported by Gautret et al. from a cohort of French patients who were treated with 600 mg of hydroxychloroquine. The study included 42 patients (26 patients treated with hydroxychloroquine and 16 patients in the control group) who were confirmed to be positive for SARSCoV-2 by RT-PCR. Of the 20 patients treated with hydroxychloroquine available for efficacy assessment, 14 (70\%) patients experienced virological cure after 6 days of treatment, whereas only $2(12.5 \%)$ patients in the control group were negative for SARS-CoV-2 after 6 days of treatment. A subgroup of patients in the hydroxychloroquine group were also treated with azithromycin (6 patients), and all of them experienced virological cure, suggesting a better efficacy for hydroxychloroquine in combination with azithromycin than hydroxychloroquine alone (100\% vs. $57 \%$, respectively) [17].

The first evidence of the efficacy of hydroxychloroquine from an RCT was published recently in the preprint server MedRxiv. The study recruited 62 patients positive for SARS-CoV-2 and randomly divided them into the test (hydroxychloroquine) and control (placebo) groups. Comparison of radiologic findings revealed that $61.3 \%$ of the patients in the hydroxychloroquine group showed significant improvement, whereas only $16.1 \%$ of those in the control group had significant improvement. The body temperature recovery time was also significantly reduced in the hydroxychloroquine group (2.2 [0.4] days) in comparison with the control group (3.2 [1.3] days). Similarly, cough remission time was also significantly reduced in the hydroxychloroquine group [18].

The efficacy of hydroxychloroquine in combination with azithromycin was also reported in a retrospective study involving French patients. A total of 1061 SARS-CoV-2-positive patients treated with hydroxychloroquine (200 $\mathrm{mg} 3$ times a day) in combination with azithromycin were included in the study (500 mg on day 1 followed by $250 \mathrm{mg}$ daily for the next 4 days). Virological cure and clinical outcomes were assessed. Approximately $92 \%$ of the patients experienced virological cure (viral culture and RT-PCR) and $95 \%$ of the patients reported alleviation of clinical symptoms. Multivariate analysis revealed older age (Odds ratio (OR): $1.11,95 \%$ confidence interval (CI) 1.07 to 1.15 ), selective beta-blocking agents (OR: $4.16,95 \% \mathrm{Cl} 1.19$ to 14.55 ), angiotensin II receptor blockers (OR: $18.40,95 \% \mathrm{Cl} 6.28$ to 53.90 ), and medium and high National Early Warning Score (NEWS; OR: $9.48,95 \% \mathrm{Cl} 3.25$ to 27.66 ; OR $=10.05,95 \% \mathrm{Cl} 3.16$ to 32.02 , respectively) were significantly associated with poor clinical outcome. Cardiac toxicity was not reported in the study [19]. Although cardiac toxicity was not reported in any of the studies, a study by Chorin et al. reported an extension in QT interval in SARS-CoV-2-positive patients treated with hydroxychloroquine, suggesting a risk of arrhythmia [20].

Despite the positive results favoring the usage of hydroxychloroquine with and without azithromycin in SARS-CoV-2-positive patients, a prospectively randomized study by Jun et al reported a lack of significantly different virological cure rates in patients treated with hydroxychloroquine in comparison with placebo. Other clinical end points such as time to body temperature normalization was also similar among the groups [21]. In another prospective single-arm study conducted by Molina et al., 11 consecutive SARS-CoV-2-positive patients treated with hydroxychloroquine were followed up for the assessment of virological and clinical outcomes. After 6 days of treatment, $80 \%$ of the patients remained virologically positive for SARS-CoV- 2 by qualitative PCR, which was in contrast to the earlier studies $(18,22)$. This was further reiterated in a recent study with a propensity-score-matched cohort of patients treated with either hydroxychloroquine alone or in combination with azithromycin or placebo. The rates of death were lower in those treated with placebo (11.4\%) compared with those treated with hydroxychloroquine alone $(27.8 \%)$ and those treated with hydroxychloroquine and azithromycin (22.1\%). The risk of ventilation was similar in all the groups. Virological cure and improvement in clinical outcomes were not assessed in this study [23].

In a recent RCT, the efficacy of hydroxychloroquine was compared with standard of care. The study recruited 150 patients confirmed to be positive for SARSCoV-2 and randomly treated with hydroxychloroquine plus standard of care (75 patients) and standard of care alone (75 patients). The primary end point was virological cure after 28 days of treatment. Virological cure probability by 28 days in hydroxychloroquine plus standard of care was $85.4 \%$ (95\% confidence interval [Cl], 73.8\% to $93.8 \%$, which was similar to that in the standard-of-care alone group $(81.3 \% ; 95 \% \mathrm{Cl}, 71.2 \%$ to $89.6 \%)$ [24]. A summary of the available evidences for hydroxychloroquine is provided in (Table 1).

Currently available early clinical evidence provides contradictory findings on the efficacy of hydroxychloroquine in SARS-CoV-2 positive patients. There are currently 125 clinical trials registered in the WHO International Clinical Trials Registry Platform (ICTRP; https://clinicaltrials.gov/ct2/who_table) and 192 studies registered in clinicaltrials.gov. The results of the ongoing studies will provide conclusive evidence on the efficacy of hydroxychloroquine in the treatment of SARS-CoV-2.

\section{Remdesivir}

Remdesivir is a nucleoside analog with proven activity against RNA viruses causing lethal hemorrhagic fever (Nipah and Ebola). It is an RNA-dependent RNA polymerase inhibitor capable of inhibiting multiple CoVs [25]. In a mouse SARS virus experimental model, the administration of remdesivir 1 day after the infection reduced the virus titer in the lungs. Similar findings were also observed with a rhesus monkey model of MERV-CoV (26, 27). The preclinical efficacy of remdesivir was confirmed in in vitro studies with Vero E6 cell lines [15].

The probable therapeutic effect of remdesivir in a patient with SARS-CoV-2 was initially reported in a case report wherein remdesivir was used on compassionate grounds. Although virological improvement and clinical cure were observed in the patient, remdesivir was used only on the sixth day of admission, and the continuous viral load testing revealed that a reduction in viral load had begun before the administration of the drug. Hence, the observed clinical effect might be due to immunity and supportive treatment [28]. A larger prospective cohort of patients treated with remdesivir on compassionate grounds were recently reported by Grein et al. [29]. Of the 61 patients who received at least 1 dose of remdesivir, 53 patients were available for follow-up. After a median follow-up of 18 days, 36 patients (68\%) had an improvement in oxygen-support class, including 17 of 30 patients (57\%) receiving mechanical ventilation. A total of 25 patients (47\%) were discharged, and 7 patients (13\%) died with a mortality was $18 \%(6$ of 34$)$ among patients receiving invasive ventilation and $5 \%$ (1 of 19) among those not receiving invasive ventilation [29]. 
The efficacy of remdesivir was recently evaluated in an RCT involving Chinese patients in comparison with placebo. The study enrolled 237 patients (158 to remdesivir and 79 to placebo) and evaluated the clinical improvement up to day 28 . The results of the study revealed a lack of significant difference in time to clinical improvement in patients treated with remdesivir in comparison with placebo (hazard ratio, 1.23 [ $95 \% \mathrm{Cl}, 0.87$ to 1.75$]$ ). In patients with symptoms for $\leq 10$ days, remdesivir showed better efficacy, $(\mathrm{HR}, 1.52$ [95\% $\mathrm{Cl}, 0.95$ to 2.43$])$, albeit without statistical significance [30].

The early clinical evidence for the efficacy of remdesivir is inconclusive with only marginal efficacy. But owing to the differences in the end points considered in the studies, the precise role of remdesivir may require larger studies with the assessment of both virological and clinical outcomes. At present, there are 22 trials registered in clinicaltrials.gov and 13 studies registered in the WHO-ICTRP.

\section{Corticosteroids}

Corticosteroids are immune modulators that suppress the inflammatory response, thereby minimizing tissue damage. The early observational evidence for the effective use of corticosteroids stems from the lower prevalence of SARS-CoV-2 infection in patients with chronic respiratory disease, suggesting a role for the drugs given for chronic respiratory disease in reducing the prevalence of SARS-CoV-2 infections in such patients [31]. The early preclinical evidence provided by Matsuyama et al. reported effective antiviral activity of ciclesonide in inhibiting the replication of SARS-CoV-2 in epithelial cell lines with an effective concentration of $6.3 \mu \mathrm{M}$ [32]. Despite the anti-inflammatory effect provided by corticosteroids, they also cause immune suppression, delaying viral clearance [33].

A recent prospective cohort study conducted by Zha et al. recruited 31 SARS-CoV-2-positive patients treated with corticosteroids (11 patients) or supportive care. The study found no statistically significant association between treatment with corticosteroids and virus clearance time (Hazards ratio (HR), 1.26 ; $95 \%$ $\mathrm{Cl}, 0.58$ to 2.74$)$, hospital length of stay ( $\mathrm{HR}, 0.77 ; 95 \% \mathrm{Cl}, 0.33$ to 1.78$)$, or duration of symptoms ( $\mathrm{HR}, 0.86 ; 95 \% \mathrm{Cl}, 0.40$ to 1.83$)$ [34]. $\mathrm{A}$ recent meta-analysis also suggested a higher relative risk for mortality and longer length of stay in patients with SARS-CoV and MERS-CoV treated with corticosteroids [35].

In a retrospective cohort study conducted by Wang et al., 46 SARS-CoV-2-positive patients treated with either corticosteroids (26) or supportive care (20) were analyzed for clinical outcomes. The mean duration for body temperature back to the normal range was significantly shorter in patients treated with corticosteroids compared with those without the administration of corticosteroids $(2.06 \pm 0.28 \mathrm{vs} .5 .29 \pm 0.70 ; P=0.010)$. The patients included in the study had severe pneumonia and were treated early with low dose of corticosteroid, suggesting favorable effect of early, low-dose treatment [36]. On the contrary, another observational study conducted by Lu et al. reported limited effect of adjuvant treatment with corticosteroids in critically ill patients [37].

The early clinical evidence for the treatment with corticosteroid remains inconclusive. There are 72 RCTs currently under progress to evaluate the efficacy of different corticosteroids at different stages of SARS-CoV-2 infection (clinicaltrials.gov).

\section{Immunotherapy With Convalescent Plasma}

The early evidence of the efficacy of convalescent sera was provided by 2 case series from China. In the first study, 5 critically ill patients with acute respiratory distress syndrome (ARDS) were administered convalescent plasma containing neutralizing IgG antibody at a titer of $>1: 1000$ that had been obtained from 5 patients previously recovered from SARS-CoV-2. All the patients were on mechanical ventilation at the time of treatment and previously treated with antiviral agents and methylprednisolone. After the treatment with convalescent sera, body temperature normalized after 3 days in 4 of the 5 patients, and viral loads also became negative after 12 days of treatment. ARDS was resolved in 4 patients after 12 days of treatment, and 3 patients were discharged [38]. In another prospective case series, 10 patients were treated with convalescent sera with a neutralizing antibody titer of $>1: 640$. The radiological examination revealed the resolution of lung lesions after 7 days and virological cure in 7 patients [39]. These findings were also substantiated by a case report of 2 elderly patients treated with convalescent sera from South Korea. Both the patients were previously treated with hydroxychloroquine and lopinavir/ritonavir. Both the patients experienced virological cure after 3 days of treatment with convalescent plasma. The resolution of lung lesions was also observed along with alleviation of other clinical symptoms [40]. Although, the evidence base for immunotherapy with convalescence plasma is supported by only weak quality evidence, it holds promise for future management strategies.

\section{Tocilizumab}

Previous studies on MERV-CoV and SARS-CoV-1 have revealed the release of a plethora of cytokines, including IL-6, which was also confirmed in SARSCoV-2 infection [41]. Hence, tocilizumab, which is a monoclonal antibody targeting the IL-6, was explored as a treatment option in the treatment of cases with severe SARS-CoV-2 infection. The earliest evidence of its efficacy was provided from a case series by Xu et al. The study included 21 patients (17 severe and 4 critical) who were treated with tocilizumab. Irrespective of the disease severity, all the patients experienced normalization of body temperature 1 day after the treatment with tocilizumab. The oxygen saturation (Sp02) levels were also improved significantly and one-third of patients on ventilator support was put on a noninvasive ventilator a day after the treatment. The percentage of lymphocytes and C-reactive proteins also returned to normal in majority of the patients after 5 days of treatment [41].

In a subsequent case report, tocilizumab was also used successfully for treating a patient with sickle cell anemia [42]. The patient was hospitalized and, on day 1, developed symptoms of SARS-CoV-2 infection, including fever $\left(38.5^{\circ} \mathrm{C}\right)$ and SpO2 dropping to $91 \%$ with crackles at pulmonary auscultation. The patient was treated with antibiotics and hydroxychloroquine at a dosage of $200 \mathrm{mg}$ orally every 8 hours while the results of RT-PCR were awaited. The patient was treated with 1 pulse of intravenous tocilizumab at a dosage of $8 \mathrm{mg} / \mathrm{kg}$ on day 2 after the deterioration of symptoms and had a positive result in RT-PCR 
for SARS-CoV-2 infection. The patient experienced clinical cure with an improvement in SpO2 and was discharged on day 5 [42]. Further clinical studies are required to substantiate the utility of tocilizumab in the treatment of SARS-CoV-2 patients.

\section{Other Antiviral Drugs}

Among the antiviral drugs, lopinavir, ritonavir, and arbidol were explored in clinical studies involving SARS-CoV-positive patients. In a prospective cohort study conducted by Ye et al., 47 patients treated with either lopinavir/ritonavir or adjuvant treatment were analyzed for efficacy outcomes. The study reported favorable outcomes with respect to lowering body temperature in patients treated with lopinavir/ritonavir in comparison with adjuvant treatment alone [43].

In a recent RCT, 50 patients with laboratory-confirmed COVID-19 were treated either with lopinavir/ritonavir (34 cases) or arbidol (16 cases). All the patients had mild to moderate SARS-CoV-2 infection without ARDS. The reduction in viral load was the primary end point. After 14 days of treatment, virological cure was observed in all the patients treated with arbidol, but 15 (44.1\%) patients treated with lopinavir/ritonavir still had detectable viral load. The study concluded the superior effect of arbidol over lopinavir/ritonavir in the treatment of cases with mild to moderate SARS-CoV infection [44]. In another RCT, 86 patients with mild to moderate SARS-CoV-2 infection were randomly assigned to the lopinavir/ritonavir group (34) or the arbidol group (35) or the no antiviral drug group (17). The primary end point was virological cure. The study reported similar rates and duration of virological cure in all the 3 groups, suggesting lack of clinical efficacy of antiviral drugs in the treatment of cases with mild to moderate SARS-CoV-2 infection [45].

\section{Preliminary Evidence and Treatment Guidelines}

Despite the good-quality early evidence, multiple treatment options were recommended by different nodal agencies. Among the treatment options, hydroxychloroquine, convalescent plasma, and remdesivir are recommended by the Food and Drug Administration (FDA) for the treatment of SARS-CoV infection under specific scenarios [46]. Hydroxychloroquine and chloroquine could be administered only for certain adolescent and adult patients hospitalized with COVID-19, as appropriate. Convalescent plasma and hyperimmune globulin could be used for the treatment based on the availability and accessibility. Remdesivir is provided with an emergency use authorization to treat suspected or laboratory-confirmed COVID-19 in adult and pediatric patients hospitalized with severe disease [47].

As per the National institute of health $(\mathrm{NIH})$ guidelines, remdesivir was recommended for the treatment of patients hospitalized with severe disease, defined as Sp02 $\leq 94 \%$ on ambient air (at sea level), requiring supplemental oxygen, mechanical ventilation, or extracorporeal membrane oxygenation. The guideline also recommends against high dose of chloroquine ( $600 \mathrm{mg}$ twice a day) because of cardiac toxicities. The NIH guidelines also recommend against the use of convalescent sera outside the context of RCTs [48].

Similarly, the Infectious Diseases Society of America (IDSA) guideline also recommends hydroxychloroquine/chloroquine/azithromycin only in the context of clinical trials and not for routine use. Lopinavir/ritonavir and convalescent sera are also recommended only in the context of clinical trials, whereas corticosteroids are recommended only for ARDS in the context of clinical trials. Corticosteroids are not recommended for the treatment of patients with mild to moderate SARS-CoV-2[49].

A recent Chinese evidence-based guideline recommended the use of a-interferon atomization inhalation (5 million units per time for adults in sterile injection water, twice a day) and lopinavir/ritonavir orally, 2 capsules each time twice a day, based on weak evidences. It also recommended 40 to $80 \mathrm{mg} / \mathrm{d}$ methylprednisolone based on weak evidence [50]. On the contrary, Indian National Guidelines for the management of SARS-CoV-2 infection recommends only short-term treatment with glucocorticoids for patients with progressive deterioration of oxygenation indicators (Table 3) [46]. But evidence from real-world studies with Indian healthcare workers have confirmed the prophylactic effect of hydroxychloroquine in health care workers. Hydroxychloroquine is recommended by the Indian council of medical research as a prophylactic drug in high-risk population [51].

\section{Perspectives on early clinical evidence}

The normal workflow in the development of treatment options for any indication involves preclinical to early clinical to late stage clinical trials. But the normal workflow is hampered in case of pandemics. Based on the early evidence available, the therapeutic options available were drugs attenuating either the immunological response (anti-inflammatory drugs) or the viral load (anti-viral agents). Since the pathogenesis of SARS-CoV-2 involves mainly inflammatory responses, the most promising drugs are anti-inflammatory drugs. The inflammatory response is also related to the viral load which makes the selection of ideal endpoint difficult. Considering the fact that the other epidemics of the current century were similar respiratory viruses, a consensus on the most appropriate end point in different categories of patients will also go a long way in mounting faster response with good quality early clinical evidence for future pandemics.

A case in point is the issue with the real-world evidence on the efficacy of hydroxychloroquine[52]. This was a multi-national registry-based study which was one of the earliest evidences in support of hydroxychloroquine for the treatment of SARS-CoV-2. But subsequent clinical trials provided contradictory results that led to the questioning of the results of the study and subsequent journal retraction. In our systematic literature review, this study was also considered as this was an early clinical evidence.

The availability of preprint servers also plays a huge role in dissemination of early stage evidences which is a milieu never faced in the past. Although this leads to faster dissemination, it can also lead to propagation of junk science. We have included evidence from preprint servers also to make a comprehensive appraisal of early stage evidence. Subsequent to the retraction of the Lancet study on hydroxychloroquine, the French study published in the preprint server 
MedRxiv was also withdrawn. Unlike the journal retractions, preprint retractions do not require substantial explanation on the reasons for retraction. This further complicated the quality of early evidence [53].

\section{Future Recommendations}

The early-stage evidence available does not convincingly supports in favor of or against a particular therapeutic regimen. This is mainly due to the heterogeneity with respect to the patients, pathogen variants, and the end points. Considering the fact that the last few pandemics were caused by respiratory viruses, drafting a consensus on the most appropriate end point will help in improving the quality of evidences in future pandemics. Furthermore, despite the availability of RCTs, they were of low quality because of the inherent bias (no data on blinding) and imprecision. Considering the fact that the field of evidence medicine is a dynamically evolving field, future studies, especially studies of importance in dealing with medical emergencies, should be appropriately designed to provide reliable and timely evidence. Although the availability of preprint servers facilitates faster dissemination of data, the non-peer-reviewed nature of content needs to be interpreted with caution.

\section{Conclusion}

The current evidence base available for different treatment options provides ambiguous results mainly because of the study designs and the end points assessed. This is also reflected on the different national treatment guidelines that were based on relatively weak evidence. The results of the ongoing clinical studies and well-designed real-world studies will improve the evidence base and may lead to further evolution of treatment guidelines with the addition of more therapeutic options. Further, a consensus on the appropriate end points for efficacy in different categories of patient may also improve the quality of evidence in case of future pandemics of respiratory viruses.

\section{Declarations}

The authors declare that they have no conflict of interest.

\section{Reproducible Research Statement:}

Data will be shared upon reasonable request from eligible researchers.

\section{Funding: None}

Compliance with ethics guidelines: This article is based on previously conducted studies and does not contain any studies with human participants or animals performed by any of the authors.

\section{References}

1. Coronavirus Disease (COVID-19) - events as they happen [Internet]. [cited 2020 May 14]. Available from: https://www.who.int/emergencies/diseases/novel-coronavirus-2019/events-as-they-happen

2. WHO. Coronavirus disease (COVID-19) Situation Report - 114 [Internet]. 2020 May. Available from: https://www.who.int/docs/defaultsource/coronaviruse/situation-reports/20200513-covid-19-sitrep-114.pdf?sfvrsn=17ebbbe_4

3. Ye Z-W, Jin D-Y. [Diagnosis, treatment, control and prevention of SARS-CoV-2 and coronavirus disease 2019: back to the future]. Sheng Wu Gong Cheng Xue Bao. 2020;36:571-92.

4. Li X, Geng M, Peng Y, Meng L, Lu S. Molecular immune pathogenesis and diagnosis of COVID-19. Journal of Pharmaceutical Analysis. 2020;10:102-8.

5. Guan W, Ni Z, Hu Y, Liang W, Ou C, He J, et al. Clinical Characteristics of Coronavirus Disease 2019 in China. New England Journal of Medicine. 2020;382:1708-20.

6. Li H, Liu L, Zhang D, Xu J, Dai H, Tang N, et al. SARS-CoV-2 and viral sepsis: observations and hypotheses. The Lancet. 2020;395:1517-20.

7. Liu J, Li S, Liu J, Liang B, Wang X, Wang H, et al. Longitudinal characteristics of lymphocyte responses and cytokine profiles in the peripheral blood of SARS-CoV-2 infected patients. medRxiv. 2020;2020.02.16.20023671.

8. Nikolich-Zugich J, Knox KS, Rios CT, Natt B, Bhattacharya D, Fain MJ. SARS-CoV-2 and COVID-19 in older adults: what we may expect regarding pathogenesis, immune responses, and outcomes. GeroScience. 2020;1-10.

9. Team TNCPERE. The Epidemiological Characteristics of an Outbreak of 2019 Novel Coronavirus Diseases (COVID-19) - China, 2020. CCDCW. 2020;2:113-22.

10. Gates B. Responding to Covid-19 - A Once-in-a-Century Pandemic? New England Journal of Medicine. 2020;382:1677-9.

11. Li X, Geng M, Peng Y, Meng L, Lu S. Molecular immune pathogenesis and diagnosis of COVID-19. Journal of Pharmaceutical Analysis. 2020;10:102-8.

12. Guyatt G, Oxman AD, Akl EA, Kunz R, Vist G, Brozek J, et al. GRADE guidelines: 1. Introduction - GRADE evidence profiles and summary of findings tables. Journal of clinical epidemiology. 2011;64:383-94.

13. Rosa SGV, Santos WC. Clinical trials on drug repositioning for COVID-19 treatment. Rev Panam Salud Publica [Internet]. 2020 [cited 2020 May 17];44. Available from: https://www.ncbi.nlm.nih.gov/pmc/articles/PMC7105280/

14. Vincent MJ, Bergeron E, Benjannet S, Erickson BR, Rollin PE, Ksiazek TG, et al. Chloroquine is a potent inhibitor of SARS coronavirus infection and spread. Virology Journal. 2005;2:69. 
15. Wang M, Cao R, Zhang L, Yang X, Liu J, Xu M, et al. Remdesivir and chloroquine effectively inhibit the recently emerged novel coronavirus (2019-nCoV) in vitro. Cell Research. 2020;30:269-71.

16. Yao X, Ye F, Zhang M, Cui C, Huang B, Niu P, et al. In Vitro Antiviral Activity and Projection of Optimized Dosing Design of Hydroxychloroquine for the Treatment of Severe Acute Respiratory Syndrome Coronavirus 2 (SARS-CoV-2). Clin Infect Dis [Internet]. [cited 2020 May 17]; Available from: https://academic.oup.com/cid/advance-article/doi/10.1093/cid/ciaa237/5801998

17. Gautret P, Lagier J-C, Parola P, Hoang VT, Meddeb L, Mailhe M, et al. Hydroxychloroquine and azithromycin as a treatment of COVID-19: results of an openlabel non-randomized clinical trial. Int J Antimicrob Agents. 2020;105949.

18. Chen Z, Hu J, Zhang Z, Jiang S, Han S, Yan D, et al. Efficacy of hydroxychloroquine in patients with COVID-19: results of a randomized clinical trial. medRxiv. 2020;2020.03.22.20040758.

19. Million M, Lagier J-C, Gautret P, Colson P, Fournier P-E, Amrane S, et al. Early treatment of COVID-19 patients with hydroxychloroquine and azithromycin: A retrospective analysis of 1061 cases in Marseille, France. Travel Medicine and Infectious Disease. 2020;101738.

20. Chorin E, Dai M, Shulman E, Wadhwani L, Cohen RB, Barbhaiya C, et al. The QT Interval in Patients with SARS-CoV-2 Infection Treated with Hydroxychloroquine/Azithromycin. medRxiv. 2020;2020.04.02.20047050.

21. A pilot study of hydroxychloroquine in treatment of patients with common coronavirus disease-19 (COVID-19) [Internet]. Epistemonikos. [cited 2020 May 17]. Available from: /en/documents/30d0f2552ff5342fbfcd1b09e9bac66d1325b467

22. Molina JM, Delaugerre C, Le Goff J, Mela-Lima B, Ponscarme D, Goldwirt L, et al. No evidence of rapid antiviral clearance or clinical benefit with the combination of hydroxychloroquine and azithromycin in patients with severe COVID-19 infection. Med Mal Infect [Internet]. 2020 [cited 2020 May 17]; Available from: https://www.ncbi.nlm.nih.gov/pmc/articles/PMC7195369/

23. Magagnoli J, Narendran S, Pereira F, Cummings T, Hardin JW, Sutton SS, et al. Outcomes of hydroxychloroquine usage in United States veterans hospitalized with Covid-19. medRxiv. 2020;2020.04.16.20065920.

24. Tang W, Cao Z, Han M, Wang Z, Chen J, Sun W, et al. Hydroxychloroquine in patients mainly with mild to moderate COVID-19: an open-label, randomized, controlled trial. medRxiv. 2020;2020.04.10.20060558.

25. Cao Y, Deng Q, Dai S. Remdesivir for severe acute respiratory syndrome coronavirus 2 causing COVID-19: An evaluation of the evidence. Travel Med Infect Dis [Internet]. 2020 [cited 2020 May 17]; Available from: https://www.ncbi.nlm.nih.gov/pmc/articles/PMC7151266/

26. Wit E de, Feldmann F, Cronin J, Jordan R, Okumura A, Thomas T, et al. Prophylactic and therapeutic remdesivir (GS-5734) treatment in the rhesus macaque model of MERS-CoV infection. PNAS. 2020;117:6771-6.

27. Sheahan TP, Sims AC, Leist SR, Schäfer A, Won J, Brown AJ, et al. Comparative therapeutic efficacy of remdesivir and combination lopinavir, ritonavir, and interferon beta against MERS-CoV. Nature Communications. 2020;11:222.

28. Holshue ML, DeBolt C, Lindquist S, Lofy KH, Wiesman J, Bruce H, et al. First Case of 2019 Novel Coronavirus in the United States. New England Journal of Medicine. 2020;382:929-36.

29. Grein J, Ohmagari N, Shin D, Diaz G, Asperges E, Castagna A, et al. Compassionate Use of Remdesivir for Patients with Severe Covid-19. New England Journal of Medicine. 2020;0:null.

30. Wang Y, Zhang D, Du G, Du R, Zhao J, Jin Y, et al. Remdesivir in adults with severe COVID-19: a randomised, double-blind, placebo-controlled, multicentre trial. The Lancet. 2020;395:1569-78.

31. Halpin DMG, Faner R, Sibila O, Badia JR, Agusti A. Do chronic respiratory diseases or their treatment affect the risk of SARS-CoV-2 infection? Lancet Respir Med. 2020;8:436-8.

32. Matsuyama S, Kawase M, Nao N, Shirato K, Ujike M, Kamitani W, et al. The inhaled corticosteroid ciclesonide blocks coronavirus RNA replication by targeting viral NSP15. bioRxiv. 2020;2020.03.11.987016.

33. Russell B, Moss C, Rigg A, Van Hemelrijck M. COVID-19 and treatment with NSAIDs and corticosteroids: should we be limiting their use in the clinical setting? Ecancermedicalscience [Internet]. 2020 [cited 2020 May 17];14. Available from: https://www.ncbi.nlm.nih.gov/pmc/articles/PMC7105332/

34. Zha L, Li S, Pan L, Tefsen B, Li Y, French N, et al. Corticosteroid treatment of patients with coronavirus disease 2019 (COVID-19). The Medical Journal of Australia. 2020;212:416-20.

35. Yang Z, Liu J, Zhou Y, Zhao X, Zhao Q, Liu J. The effect of corticosteroid treatment on patients with coronavirus infection: a systematic review and metaanalysis. J Infect [Internet]. 2020 [cited 2020 May 17]; Available from: https://www.ncbi.nlm.nih.gov/pmc/articles/PMC7195158/

36. Wang Y, Jiang W, He Q, Wang C, Wang B, Zhou P, et al. Early, low-dose and short-term application of corticosteroid treatment in patients with severe COVID-19 pneumonia: single-center experience from Wuhan, China. medRxiv. 2020;2020.03.06.20032342.

37. Lu X, Chen T, Wang Y, Wang J, Zhang B, Li Y, et al. Adjuvant corticosteroid therapy for critically ill patients with COVID-19. medRxiv. 2020;2020.04.07.20056390.

38. Shen C, Wang Z, Zhao F, Yang Y, Li J, Yuan J, et al. Treatment of 5 Critically III Patients With COVID-19 With Convalescent Plasma. JAMA. 2020;323:15829.

39. Duan K, Liu B, Li C, Zhang H, Yu T, Qu J, et al. Effectiveness of convalescent plasma therapy in severe COVID-19 patients. Proc Natl Acad Sci USA. 2020;117:9490-6.

40. Ahn JY, Sohn Y, Lee SH, Cho Y, Hyun JH, Baek YJ, et al. Use of Convalescent Plasma Therapy in Two COVID-19 Patients with Acute Respiratory Distress Syndrome in Korea. J Korean Med Sci [Internet]. 2020 [cited 2020 May 18];35. Available from: https://www.ncbi.nlm.nih.gov/pmc/articles/PMC7152526/

41. Xu X, Han M, Li T, Sun W, Wang D, Fu B, et al. Effective treatment of severe COVID-19 patients with tocilizumab. PNAS. 2020;117:10970-5. 
42. Luna GD, Habibi A, Deux J-F, Colard M, d' Orengiani A-LPH d'Alexandry, Schlemmer F, et al. Rapid and severe Covid-19 pneumonia with severe acute chest syndrome in a sickle cell patient successfully treated with tocilizumab. American Journal of Hematology [Internet]. [cited 2020 May 21];n/a. Available from: https://onlinelibrary.wiley.com/doi/abs/10.1002/ajh.25833

43. Ye X-T, Luo Y-L, Xia S-C, Sun Q-F, Ding J-G, Zhou Y, et al. Clinical efficacy of lopinavir/ritonavir in the treatment of Coronavirus disease 2019. Eur Rev Med Pharmacol Sci. 2020;24:3390-6.

44. Zhu Z, Lu Z, Xu T, Chen C, Yang G, Zha T, et al. Arbidol monotherapy is superior to lopinavir/ritonavir in treating COVID-19. J Infect [Internet]. 2020 [cited 2020 May 18]; Available from: https://www.ncbi.nlm.nih.gov/pmc/articles/PMC7195393/

45. Li Y, Xie Z, Lin W, Cai W, Wen C, Guan Y, et al. An exploratory randomized controlled study on the efficacy and safety of lopinavir/ritonavir or arbidol treating adult patients hospitalized with mild/moderate COVID-19 (ELACOI). medRxiv. 2020;2020.03.19.20038984.

46. Revised Guidelines on Clinical Management of COVID - 19 [Internet]. 2020 Mar. Available from: https://www.mohfw.gov.in/pdf/RevisedNationalClinicalManagementGuidelineforCOVID1931032020.pdf

47. Commissioner 0 of the. Coronavirus Disease 2019 (COVID-19) [Internet]. FDA. 2020 [cited 2020 May 18]. Available from: https://www.fda.gov/emergencypreparedness-and-response/counterterrorism-and-emerging-threats/coronavirus-disease-2019-covid-19

48. Immune-Based Therapy | Coronavirus Disease COVID-19 [Internet]. COVID-19 Treatment Guidelines. [cited 2020 May 18]. Available from: https://www.covid19treatmentguidelines.nih.gov/immune-based-therapy/

49. Infectious Diseases Society of America Guidelines on the Treatment and Management of Patients with COVID-19 [Internet]. 2020 Apr. Available from: https://www.idsociety.org/practice-guideline/covid-19-guideline-treatment-and-management/

50. Jin Y-H, Cai L, Cheng Z-S, Cheng H, Deng T, Fan Y-P, et al. A rapid advice guideline for the diagnosis and treatment of 2019 novel coronavirus (2019-nCoV) infected pneumonia (standard version). Military Medical Research. 2020;7:4.

51. DelhiJune 1 MSN, June 1 2020UPDATED:, Ist 2020 07:56. 4 or more hydroxychloroquine doses reduced risk of coronavirus in healthcare workers: ICMR study [Internet]. India Today. [cited 2020 Jun 1]. Available from: https://www.indiatoday.in/india/story/4-hydroxychloroquine-hcq-doses-coronavirushealthcare-workers-icmr-1684112-2020-06-01

52. Mehra MR, Desai SS, Ruschitzka F, Patel AN. RETRACTED: Hydroxychloroquine or chloroquine with or without a macrolide for treatment of COVID-19: a multinational registry analysis. Lancet. 2020;

53. Oransky Al. French hydroxychloroquine-COVID-19 study withdrawn [Internet]. Retraction Watch. 2020 [cited 2020 Jun 30 ]. Available from: https://retractionwatch.com/2020/05/21/french-hydroxychloroquine-covid-19-study-withdrawn/

\section{Tables}

Table 1. Early Clinical Evidences for the Treatment of SARS-CoV-2 


\begin{tabular}{|c|c|c|c|c|c|c|c|c|}
\hline S.no & $\begin{array}{l}\text { Study } \\
\text { Name }\end{array}$ & Study Type & Intervention ( $n)$ & Dose & Control Group (n) & Dose & $\begin{array}{l}\text { Outcome/End } \\
\text { Points }\end{array}$ & Conclusic \\
\hline 1. & $\begin{array}{l}\text { Gautret et } \\
\text { al.(17) }\end{array}$ & $\begin{array}{l}\text { Prospective } \\
\text { cohort study }\end{array}$ & $\begin{array}{l}\text { Hydroxychloroquine } \\
\text { alone or in } \\
\text { combination with } \\
\text { azithromycin (26) }\end{array}$ & $\begin{array}{l}600-\mathrm{mg} \\
\text { hydroxychloroquine } \\
\text { daily and } 500-\mathrm{mg} \\
\text { azithromycin on } \\
\text { day } 1 \text { followed by } \\
250 \text { mg for days } 2- \\
5\end{array}$ & $\begin{array}{l}\text { Supportive care } \\
\text { (16) }\end{array}$ & - & $\begin{array}{l}\text { Virological } \\
\text { cure }\end{array}$ & $\begin{array}{l}\text { Favors tre } \\
\text { with azith }\end{array}$ \\
\hline 2. & $\begin{array}{l}\text { Jun et al. } \\
(21)\end{array}$ & $\begin{array}{l}\text { Prospectively } \\
\text { randomized } \\
\text { study }\end{array}$ & $\begin{array}{l}\text { Hydroxychloroquine } \\
\text { (15) }\end{array}$ & $\begin{array}{l}400-\mathrm{mg} \\
\text { hydroxychloroquine } \\
\text { for } 5 \text { days plus } \\
\text { conventional } \\
\text { treatment }\end{array}$ & $\begin{array}{l}\text { Conventional } \\
\text { supportive } \\
\text { treatment (15) }\end{array}$ & - & $\begin{array}{l}\text { Virological } \\
\text { cure }\end{array}$ & $\begin{array}{l}\text { No signifi } \\
\text { difference } \\
\text { rates of v } \\
\text { cure }\end{array}$ \\
\hline 3. & $\begin{array}{l}\text { Zhaowei } \\
\text { et al.(18) }\end{array}$ & $\begin{array}{l}\text { Randomized } \\
\text { controlled } \\
\text { study }\end{array}$ & $\begin{array}{l}\text { Hydroxychloroquine } \\
\text { (31) }\end{array}$ & $\begin{array}{l}400-\mathrm{mg} \\
\text { hydroxychloroquine } \\
\text { for } 5 \text { days }\end{array}$ & $\begin{array}{l}\text { Standard } \\
\text { supportive care } \\
\text { (31) }\end{array}$ & - & $\begin{array}{l}\text { Virological } \\
\text { and clinical } \\
\text { outcomes }\end{array}$ & $\begin{array}{l}\text { Treatmen } \\
\text { hydroxycl } \\
\text { significan } \\
\text { improved } \\
\text { virologica } \\
\text { alleviatior } \\
\text { clinical sy }\end{array}$ \\
\hline 4. & $\begin{array}{l}\text { Molina et } \\
\text { al.(22) }\end{array}$ & $\begin{array}{l}\text { Single-arm, } \\
\text { prospective, } \\
\text { cohort study }\end{array}$ & $\begin{array}{l}\text { Hydroxychloroquine } \\
\text { and azithromycin } \\
\text { (11) }\end{array}$ & $\begin{array}{l}600-\mathrm{mg} \\
\text { hydroxychloroquine } \\
\text { daily for } 10 \text { days } \\
\text { and } 500-\mathrm{mg} \\
\text { azithromycin on } \\
\text { day } 1 \text { followed by } \\
250 \text { mg for days } 2- \\
5\end{array}$ & - & & $\begin{array}{l}\text { Virological } \\
\text { cure }\end{array}$ & $\begin{array}{l}\text { No virolos } \\
\text { in majorit } \\
\text { patients }\end{array}$ \\
\hline 5. & $\begin{array}{l}\text { Chorin et } \\
\text { al.(20) }\end{array}$ & $\begin{array}{l}\text { Single-arm } \\
\text { study }\end{array}$ & $\begin{array}{l}\text { Hydroxychloroquine } \\
\text { (84) }\end{array}$ & & - & & Safety & $\begin{array}{l}\text { Hydroxyc } \\
\text { extended } \\
\text { interval, ir } \\
\text { the risk of } \\
\text { arrythmia }\end{array}$ \\
\hline 6. & $\begin{array}{l}\text { Million et } \\
\text { al.(19) }\end{array}$ & $\begin{array}{l}\text { Single-arm, } \\
\text { retrospective, } \\
\text { cohort study }\end{array}$ & $\begin{array}{l}\text { Hydroxychloroquine } \\
\text { and azithromycin } \\
\text { (1061) }\end{array}$ & $\begin{array}{l}200 \mathrm{mg} 3 \text { times a } \\
\text { day for } 10 \text { days } \\
\text { and } 500-\mathrm{mg} \\
\text { azithromycin on } \\
\text { day } 1 \text { followed by } \\
250 \text { mg for days } 2- \\
5\end{array}$ & - & & $\begin{array}{l}\text { Virological } \\
\text { and clinical } \\
\text { cure }\end{array}$ & $\begin{array}{l}\text { High rates } \\
\text { virologica } \\
\text { clinical al } \\
\text { of symptc } \\
\text { observed } \\
\text { patients }\end{array}$ \\
\hline 7. & $\begin{array}{l}\text { Magognoli } \\
\text { et al.(23) }\end{array}$ & $\begin{array}{l}\text { Retrospective, } \\
\text { propensity- } \\
\text { score- } \\
\text { matched } \\
\text { cohort }\end{array}$ & $\begin{array}{l}\text { Hydroxychloroquine } \\
\text { and azithromycin } \\
\text { (210) }\end{array}$ & Not available & $\begin{array}{l}\text { Supportive care } \\
\text { (158) }\end{array}$ & - & $\begin{array}{l}\text { Death and } \\
\text { rates of } \\
\text { ventilation }\end{array}$ & $\begin{array}{l}\text { Lower rat } \\
\text { death in } \mathrm{t} \\
\text { group } \\
\text { Similar ra } \\
\text { ventilatiol } \\
\text { interventi, } \\
\text { control gr }\end{array}$ \\
\hline 8. & $\begin{array}{l}\text { Tang et al. } \\
(24)\end{array}$ & $\begin{array}{l}\text { Randomized } \\
\text { controlled } \\
\text { study }\end{array}$ & $\begin{array}{l}\text { Hydroxychloroquine } \\
\text { plus standard of } \\
\text { care (75) }\end{array}$ & $\begin{array}{l}1200 \mathrm{mg} \text { daily for } 3 \\
\text { days followed by } \\
800 \mathrm{mg} \text { daily }\end{array}$ & $\begin{array}{l}\text { Standard of care } \\
\text { alone }(75)\end{array}$ & - & $\begin{array}{l}\text { Virological } \\
\text { cure }\end{array}$ & $\begin{array}{l}\text { Virologica } \\
\text { rates wert } \\
\text { both the } \\
\text { interventi } \\
\text { control gr } \\
28 \text { days o } \\
\text { treatment }\end{array}$ \\
\hline 9. & $\begin{array}{l}\text { Holshue et } \\
\text { al.(28) }\end{array}$ & Case report & Remdesivir (1) & Not available & - & - & $\begin{array}{l}\text { Virological } \\
\text { cure }\end{array}$ & $\begin{array}{l}\text { Reductior } \\
\text { load obse } \\
\text { response } \\
\text { due to im } \\
\text { supportiv }\end{array}$ \\
\hline 10. & $\begin{array}{l}\text { Grein et al. } \\
(29)\end{array}$ & $\begin{array}{l}\text { Single-arm, } \\
\text { prospective } \\
\text { cohort }\end{array}$ & Remdesivir (61) & $\begin{array}{l}200 \mathrm{mg} \text { on day } 1 \\
\text { and } 100 \mathrm{mg} \text { for } \\
\text { days } 2-9\end{array}$ & - & - & Clinical cure & $\begin{array}{l}68 \% \text { of th } \\
\text { experienc } \\
\text { improver } \\
\text { symptom }\end{array}$ \\
\hline 11. & $\begin{array}{l}\text { Wang et } \\
\text { al.(30) }\end{array}$ & $\begin{array}{l}\text { Randomized } \\
\text { controlled } \\
\text { trial }\end{array}$ & Remdesivir (158) & $\begin{array}{l}200 \mathrm{mg} \text { on day } 1 \\
\text { and } 100 \mathrm{mg} \text { for } \\
\text { days } 2-9\end{array}$ & $\begin{array}{l}\text { Supportive care } \\
(79)\end{array}$ & - & Clinical cure & $\begin{array}{l}\text { No signifi } \\
\text { difference } \\
\text { time to cli } \\
\text { improven } \\
\text { among th }\end{array}$ \\
\hline 12. & $\begin{array}{l}\text { Zha et al. } \\
\text { (34) }\end{array}$ & $\begin{array}{l}\text { Prospective } \\
\text { cohort }\end{array}$ & Corticosteroid (11) & $\begin{array}{l}40-\mathrm{mg} \\
\text { methylprednisolone } \\
\text { once daily or twice } \\
\text { a day }\end{array}$ & $\begin{array}{l}\text { Supportive care } \\
(20)\end{array}$ & - & Clinical cure & $\begin{array}{l}\text { No signifi } \\
\text { improver } \\
\text { patients } t \\
\text { with corti }\end{array}$ \\
\hline 13. & $\begin{array}{l}\text { Wang et } \\
\text { al.(36) }\end{array}$ & $\begin{array}{l}\text { Prospective } \\
\text { cohort }\end{array}$ & $\begin{array}{l}\text { Early, low-dose, } \\
\text { corticosteroids (26) }\end{array}$ & $\begin{array}{l}1-2 \mathrm{mg} / \mathrm{kg} / \text { day for } \\
5-7 \text { days }\end{array}$ & $\begin{array}{l}\text { Supportive care } \\
(20)\end{array}$ & & Clinical cure & $\begin{array}{l}\text { Significar } \\
\text { improver }\end{array}$ \\
\hline
\end{tabular}




\begin{tabular}{|c|c|c|c|c|c|c|c|c|}
\hline 14. & $\begin{array}{l}\text { Lu et al. } \\
(37)\end{array}$ & $\begin{array}{l}\text { Retrospective } \\
\text { cohort }\end{array}$ & $\begin{array}{l}\text { Adjuvant } \\
\text { corticosteroid (151) }\end{array}$ & $\begin{array}{l}\text { hydrocortisone- } \\
\text { equivalent dosage } \\
\text { range: } 100-800 \\
\text { mg/d }\end{array}$ & $\begin{array}{l}\text { Supportive care } \\
(93)\end{array}$ & - & Clinical cure & $\begin{array}{l}\text { No signifi } \\
\text { difference } \\
\text { the treatr } \\
\text { groups }\end{array}$ \\
\hline 15. & $\begin{array}{l}\text { Shen et al. } \\
(38)\end{array}$ & Case series & $\begin{array}{l}\text { Convalescent } \\
\text { plasma (5) }\end{array}$ & $\begin{array}{l}>1: 1000 \text { end point } \\
\text { dilution titer }\end{array}$ & - & & $\begin{array}{l}\text { Virological } \\
\text { and clinical } \\
\text { cure }\end{array}$ & $\begin{array}{l}\text { Resolutio } \\
\text { clinical sy } \\
\text { and reduc } \\
\text { viral load }\end{array}$ \\
\hline 16. & $\begin{array}{l}\text { Duan et al. } \\
(39)\end{array}$ & Case series & $\begin{array}{l}\text { Convalescent } \\
\text { plasma (10) }\end{array}$ & $\begin{array}{l}>1: 640 \text { neutralizing } \\
\text { antibody titer }\end{array}$ & - & & $\begin{array}{l}\text { Virological } \\
\text { and clinical } \\
\text { cure }\end{array}$ & $\begin{array}{l}\text { Resolutio } \\
\text { clinical sy } \\
\text { and reduc } \\
\text { viral load }\end{array}$ \\
\hline 17. & $\begin{array}{l}\text { Young et } \\
\text { al.(40) }\end{array}$ & Case report & $\begin{array}{l}\text { Convalescent } \\
\text { plasma (2) }\end{array}$ & $\begin{array}{l}\text { Optical density of } \\
\text { lgG of } 0.586 \\
\text { divided into } 2 \\
\text { doses at } 12-h \\
\text { interval }\end{array}$ & - & & $\begin{array}{l}\text { Virological } \\
\text { and clinical } \\
\text { cure }\end{array}$ & $\begin{array}{l}\text { Resolutio } \\
\text { clinical sy } \\
\text { and reduc } \\
\text { viral load }\end{array}$ \\
\hline 18. & $\begin{array}{l}\text { Zhu et al. } \\
(44)\end{array}$ & $\mathrm{RCT}$ & Arbidol (16) & $\begin{array}{l}0.2-g \text { arbidol } 3 \\
\text { times a day }\end{array}$ & $\begin{array}{l}\text { Lopinavir/ritonavir } \\
\text { (34) }\end{array}$ & $\begin{array}{l}400 \mathrm{mg} / 100 \mathrm{mg} \\
\text { of } \\
\text { lopinavir/ritonavir } \\
\text { twice a day for a } \\
\text { week }\end{array}$ & $\begin{array}{l}\text { Virological } \\
\text { cure }\end{array}$ & $\begin{array}{l}\text { Arbidol is } \\
\text { in cases v } \\
\text { to moderc } \\
\text { CoV infec }\end{array}$ \\
\hline 19. & $\begin{array}{l}\text { Li et al. } \\
(45)\end{array}$ & $\mathrm{RCT}$ & $\begin{array}{l}\text { Arbidol and } \\
\text { lopinavir/ritonavir } \\
(69)\end{array}$ & $\begin{array}{l}200-\text { mg lopinavir } \\
\text { and } 50 \text {-mg rotinavir } \\
\text { twice a day or } 200 \\
\text { mg arbidol } 3 \text { times } \\
\text { a day }\end{array}$ & $\begin{array}{l}\text { No antiviral drug } \\
(17)\end{array}$ & - & $\begin{array}{l}\text { Virological } \\
\text { cure }\end{array}$ & $\begin{array}{l}\text { No signifi } \\
\text { difference } \\
\text { the treatr } \\
\text { groups }\end{array}$ \\
\hline 20. & $\begin{array}{l}\text { Ye et al. } \\
(43)\end{array}$ & $\begin{array}{l}\text { Prospective } \\
\text { cohort }\end{array}$ & $\begin{array}{l}\text { Lopinavir/ritonavir } \\
\text { plus adjuvant } \\
\text { treatment (42) }\end{array}$ & $\begin{array}{l}\text { 80-mg lopinavir } \\
\text { and 20-mg ritonavir }\end{array}$ & $\begin{array}{l}\text { Adjuvant } \\
\text { treatment alone } \\
\text { (5) }\end{array}$ & - & Clinical cure & $\begin{array}{l}\text { Treatmen } \\
\text { lopinavir/ } \\
\text { led to nor } \\
\text { of body } \\
\text { temperatı }\end{array}$ \\
\hline 21 & $\begin{array}{l}\text { Xu et al. } \\
(41)\end{array}$ & $\begin{array}{l}\text { Prospective } \\
\text { cohort }\end{array}$ & Tocilizumab (20) & $400-800 \mathrm{mg}$ & - & - & Clinical cure & $\begin{array}{l}\text { All the pa: } \\
\text { experienc } \\
\text { normalize } \\
\text { body tem } \\
\text { and were } \\
\text { stable aft } \\
\text { of treatmı }\end{array}$ \\
\hline 22 & $\begin{array}{l}\text { Luna et al. } \\
(42)\end{array}$ & Case report & Tocilizumab (1) & $8 \mathrm{mg} / \mathrm{kg}$ & - & & Clinical cure & $\begin{array}{l}\text { Patient's } \\
\text { improved } \\
\text { to } 97 \% \text { an } \\
\text { patient Wi } \\
\text { apyrexic }\end{array}$ \\
\hline
\end{tabular}

Table 2. GRADE Evidence Profile 


\begin{tabular}{|c|c|c|c|c|c|c|c|c|c|}
\hline \multirow[t]{2}{*}{ Outcome } & \multicolumn{7}{|c|}{ Certainty Assessment } & \multicolumn{2}{|c|}{ No. of Patients } \\
\hline & Study ID & Study Design & $\begin{array}{l}\text { Risk of } \\
\text { Bias }\end{array}$ & Inconsistency & Indirectness & Imprecision & $\begin{array}{l}\text { Other } \\
\text { Considerations }\end{array}$ & Intervention & Comparator \\
\hline Mortality & $\begin{array}{l}\text { Jun et al. } \\
(21)\end{array}$ & RCT & serious & Not serious & Not serious & $\begin{array}{l}\text { Very } \\
\text { serious }\end{array}$ & None & $0 / 15$ & $0 / 15$ \\
\hline $\begin{array}{l}\text { Failure of } \\
\text { virologic } \\
\text { clearance }\end{array}$ & $\begin{array}{l}\text { Jun et al. } \\
(21)\end{array}$ & RCT & serious & Not serious & Serious & $\begin{array}{l}\text { Very } \\
\text { serious }\end{array}$ & None & $2 / 15$ & $1 / 15$ \\
\hline $\begin{array}{l}\text { Clinical } \\
\text { improvement }\end{array}$ & $\begin{array}{l}\text { Zhaowei } \\
\text { et al.(18) }\end{array}$ & RCT & serious & Not serious & Serious & Serious & None & $25 / 31$ & $17 / 31$ \\
\hline $\begin{array}{l}\text { Virological } \\
\text { cure }\end{array}$ & $\begin{array}{l}\text { Gautret et } \\
\text { al.(17) }\end{array}$ & $\begin{array}{l}\text { Prospective } \\
\text { cohort }\end{array}$ & $\begin{array}{l}\text { Very } \\
\text { serious }\end{array}$ & Serious & Not serious & Serious & None & $70 \%$ & $12.5 \%$ \\
\hline $\begin{array}{l}\text { Virological } \\
\text { cure }\end{array}$ & $\begin{array}{l}\text { Molina et } \\
\text { al.(22) }\end{array}$ & $\begin{array}{l}\text { Single-arm } \\
\text { study }\end{array}$ & $\begin{array}{l}\text { Very } \\
\text { serious }\end{array}$ & Serious & Serious & Serious & None & $2 / 11$ & - \\
\hline Mortality & $\begin{array}{l}\text { Molina et } \\
\text { al.(22) }\end{array}$ & $\begin{array}{l}\text { Single-arm } \\
\text { study }\end{array}$ & $\begin{array}{l}\text { Very } \\
\text { serious }\end{array}$ & Serious & Serious & Serious & None & $1 / 11$ & - \\
\hline QT interval & $\begin{array}{l}\text { Chorin et } \\
\text { al.(20) }\end{array}$ & $\begin{array}{l}\text { Single-arm } \\
\text { study }\end{array}$ & $\begin{array}{l}\text { Very } \\
\text { serious }\end{array}$ & Serious & Serious & Serious & None & $11 \%$ & - \\
\hline Mortality & $\begin{array}{l}\text { Million et } \\
\text { al.(19) }\end{array}$ & $\begin{array}{l}\text { Single-arm, } \\
\text { retrospective, } \\
\text { cohort study }\end{array}$ & $\begin{array}{l}\text { Very } \\
\text { serious }\end{array}$ & Serious & Serious & Not serious & None & $8 / 1061$ & - \\
\hline $\begin{array}{l}\text { Virological } \\
\text { cure }\end{array}$ & $\begin{array}{l}\text { Million et } \\
\text { al.(19) }\end{array}$ & $\begin{array}{l}\text { Single-arm, } \\
\text { retrospective, } \\
\text { cohort study }\end{array}$ & $\begin{array}{l}\text { Very } \\
\text { serious }\end{array}$ & Serious & Serious & Not serious & None & $973 / 1061$ & - \\
\hline Mortality & $\begin{array}{l}\text { Magognoli } \\
\text { et al.(23) }\end{array}$ & $\begin{array}{l}\text { Retrospective, } \\
\text { propensity- } \\
\text { score- } \\
\text { matched } \\
\text { cohort }\end{array}$ & $\begin{array}{l}\text { Very } \\
\text { serious }\end{array}$ & Not serious & Not serious & Not serious & None & $51 / 210$ & $18 / 158$ \\
\hline $\begin{array}{l}\text { Rates of } \\
\text { ventilation }\end{array}$ & $\begin{array}{l}\text { Magognoli } \\
\text { et al.(23) }\end{array}$ & $\begin{array}{l}\text { Retrospective, } \\
\text { propensity- } \\
\text { score- } \\
\text { matched } \\
\text { cohort }\end{array}$ & $\begin{array}{l}\text { Very } \\
\text { serious }\end{array}$ & Not serious & Serious & Not serious & None & $21 / 210$ & $22 / 158$ \\
\hline $\begin{array}{l}\text { Virological } \\
\text { cure }\end{array}$ & $\begin{array}{l}\text { Tang et al. } \\
(24)\end{array}$ & $\begin{array}{l}\text { Randomized } \\
\text { controlled } \\
\text { study }\end{array}$ & $\begin{array}{l}\text { Very } \\
\text { serious }\end{array}$ & Serious & Serious & Not serious & None & $64 / 75$ & $61 / 75$ \\
\hline Clinical cure & $\begin{array}{l}\text { Holshue et } \\
\text { al.(28) }\end{array}$ & Case report & $\begin{array}{l}\text { Very } \\
\text { serious }\end{array}$ & Not serious & Not serious & $\begin{array}{l}\text { very } \\
\text { serious }\end{array}$ & None & $1 / 1$ & - \\
\hline $\begin{array}{l}\text { Extubation of } \\
\text { mechanical } \\
\text { ventilation }\end{array}$ & $\begin{array}{l}\text { Grein et al. } \\
(29)\end{array}$ & $\begin{array}{l}\text { Single-arm, } \\
\text { prospective } \\
\text { cohort }\end{array}$ & & & & & & $17 / 30$ & \\
\hline Mortality & $\begin{array}{l}\text { Grein et al. } \\
(29)\end{array}$ & $\begin{array}{l}\text { Single-arm, } \\
\text { prospective } \\
\text { cohort }\end{array}$ & $\begin{array}{l}\text { Very } \\
\text { serious }\end{array}$ & Serious & Serious & Serious & None & $7 / 61$ & - \\
\hline $\begin{array}{l}\text { Body } \\
\text { temperature }\end{array}$ & $\begin{array}{l}\text { Wang et } \\
\text { al.(36) }\end{array}$ & $\begin{array}{l}\text { Prospective } \\
\text { cohort }\end{array}$ & $\begin{array}{l}\text { Very } \\
\text { serious }\end{array}$ & Serious & Serious & Serious & None & $\begin{array}{l}2.06 \pm \\
0.28\end{array}$ & $5.29 \pm 0.70$ \\
\hline Mortality & $\begin{array}{l}\text { Lu et al. } \\
\text { (37) }\end{array}$ & $\begin{array}{l}\text { Retrospective } \\
\text { cohort }\end{array}$ & $\begin{array}{l}\text { Very } \\
\text { serious }\end{array}$ & Serious & Serious & Serious & None & $12 / 31$ & $5 / 31$ \\
\hline $\begin{array}{l}\text { Body } \\
\text { temperature } \\
\text { normalization }\end{array}$ & $\begin{array}{l}\text { Shen et al. } \\
\text { (38) }\end{array}$ & Case series & $\begin{array}{l}\text { Not } \\
\text { serious }\end{array}$ & Not serious & $\begin{array}{l}\text { Very } \\
\text { serious }\end{array}$ & Not serious & None & $4 / 5$ & - \\
\hline $\begin{array}{l}\text { Virological } \\
\text { cure }\end{array}$ & $\begin{array}{l}\text { Shen et al. } \\
\text { (38) }\end{array}$ & Case series & $\begin{array}{l}\text { Not } \\
\text { serious }\end{array}$ & Not serious & $\begin{array}{l}\text { Very } \\
\text { serious }\end{array}$ & Not serious & & $5 / 5$ & - \\
\hline Clinical cure & $\begin{array}{l}\text { Duan et al. } \\
\text { (39) }\end{array}$ & Case series & $\begin{array}{l}\text { Not } \\
\text { serious }\end{array}$ & Not serious & $\begin{array}{l}\text { Very } \\
\text { serious }\end{array}$ & Not serious & & $10 / 10$ & - \\
\hline $\begin{array}{l}\text { Absorption of } \\
\text { pulmonary } \\
\text { lesions }\end{array}$ & $\begin{array}{l}\text { Duan et al. } \\
\text { (39) }\end{array}$ & Case series & $\begin{array}{l}\text { Not } \\
\text { serious }\end{array}$ & Not serious & $\begin{array}{l}\text { Very } \\
\text { serious }\end{array}$ & Not serious & & $10 / 10$ & - \\
\hline Virological & Young et & Case series & Not & Not serious & Very & Not serious & & $2 / 2 /$ & - \\
\hline
\end{tabular}




\begin{tabular}{|c|c|c|c|c|c|c|c|c|}
\hline cure & al.(40) & & serious & & serious & & & \\
\hline $\begin{array}{l}\text { Virological } \\
\text { cure }\end{array}$ & $\begin{array}{l}\text { Zhu et al. } \\
(44)\end{array}$ & RCT & Serious & Not serious & Not serious & Not serious & $16 / 16$ & $19 / 34$ \\
\hline $\begin{array}{l}\text { Virological } \\
\text { cure }\end{array}$ & $\begin{array}{l}\text { Li et al. } \\
(45)\end{array}$ & RCT & Serious & Not serious & Serious & Serious & $25 / 69$ & $7 / 17$ \\
\hline $\begin{array}{l}\text { Days to } \\
\text { normalization } \\
\text { of body } \\
\text { temperature }\end{array}$ & $\begin{array}{l}\text { Ye et al. } \\
(43)\end{array}$ & $\begin{array}{l}\text { Prospective } \\
\text { cohort }\end{array}$ & $\begin{array}{l}\text { Very } \\
\text { serious }\end{array}$ & Not serious & Serious & Not serious & $4.8 \pm 1.94$ & $7.3 \pm 1.53$ \\
\hline $\begin{array}{l}\text { Body } \\
\text { temperature } \\
\text { normalization }\end{array}$ & $\begin{array}{l}\text { Xu et al. } \\
(41)\end{array}$ & $\begin{array}{l}\text { Prospective } \\
\text { cohort }\end{array}$ & $\begin{array}{l}\text { Very } \\
\text { serious }\end{array}$ & Not serious & Serious & Not serious & $20 / 20$ & - \\
\hline $\begin{array}{l}\text { Virological } \\
\text { cure }\end{array}$ & $\begin{array}{l}\text { Luna et al. } \\
(42)\end{array}$ & Case report & $\begin{array}{l}\text { Very } \\
\text { serious }\end{array}$ & Very serious & Not serious & Not serious & $1 / 1$ & - \\
\hline
\end{tabular}

$\mathrm{RR}$; relative risk.

Table 3. Treatment Recommendation from Different Guidelines

\begin{tabular}{|c|c|c|c|}
\hline Guideline & Drugs Recommended & Context & Contraindications \\
\hline \multirow[t]{3}{*}{ Combating COVID-19 with therapeutics, FDA, May 2020} & Hydroxychloroquine & $\begin{array}{l}\text { Adolescent and } \\
\text { adult patients } \\
\text { hospitalized with } \\
\text { COVID-19 }\end{array}$ & \multirow[t]{3}{*}{$\begin{array}{l}\text { No specific } \\
\text { recommendation } \\
\text { because of lack } \\
\text { of evidence. }\end{array}$} \\
\hline & Remdesivir & $\begin{array}{l}\text { Adult and } \\
\text { pediatric patients } \\
\text { hospitalized with } \\
\text { severe disease }\end{array}$ & \\
\hline & $\begin{array}{l}\text { Convalescent plasma and hyperimmune } \\
\text { globulin }\end{array}$ & $\begin{array}{l}\text { Based on } \\
\text { availability }\end{array}$ & \\
\hline \multirow{2}{*}{$\begin{array}{l}\text { COVID-19 Treatment Guidelines Panel, National Institute of } \\
\text { Health, May } 2020\end{array}$} & Remdesivir & Severe disease & \multirow{2}{*}{$\begin{array}{l}\text { No specific } \\
\text { recommendation } \\
\text { because of lack } \\
\text { of evidence. }\end{array}$} \\
\hline & Convalescent sera & $\begin{array}{l}\text { Only in the } \\
\text { context of RCTs }\end{array}$ & \\
\hline \multirow{5}{*}{$\begin{array}{l}\text { Guidelines for treatment and management of patients with } \\
\text { COVID-19, Infectious Diseases Society of America, April, } \\
2020\end{array}$} & Hydroxychloroquine/chloroquine/azithromycin & $\begin{array}{l}\text { Only in the } \\
\text { context of RCTs }\end{array}$ & \multirow{5}{*}{$\begin{array}{l}\text { No specific } \\
\text { recommendation } \\
\text { because of lack } \\
\text { of evidence. }\end{array}$} \\
\hline & Lopinavir/ritonavir & $\begin{array}{l}\text { Only in the } \\
\text { context of RCTs }\end{array}$ & \\
\hline & Convalescent sera & $\begin{array}{l}\text { Only in the } \\
\text { context of RCTs }\end{array}$ & \\
\hline & Tocilizumab & $\begin{array}{l}\text { Only in the } \\
\text { context of RCTs }\end{array}$ & \\
\hline & Corticosteroids & $\begin{array}{l}\text { Patients with } \\
\text { ARDS only in the } \\
\text { context of clinical } \\
\text { trials }\end{array}$ & \\
\hline \multirow[t]{3}{*}{ Chinese rapid advice guideline, February, 2020} & a-Interferon atomization inhalation & \multirow[t]{3}{*}{ Based on severity } & \multirow{3}{*}{$\begin{array}{l}\text { No specific } \\
\text { recommendation } \\
\text { because of lack } \\
\text { of evidence. }\end{array}$} \\
\hline & Lopinavir/ritonavir & & \\
\hline & Methylprednisolone & & \\
\hline $\begin{array}{l}\text { Revised Guidelines on Clinical Management of COVID-19, } \\
\text { Indian National Guideline, March, } 2020\end{array}$ & Corticosteroids & $\begin{array}{l}\text { Patients with } \\
\text { progressive } \\
\text { deterioration of } \\
\text { lung function }\end{array}$ & $\begin{array}{l}\text { Early pregnancy } \\
\text { should be } \\
\text { terminated. }\end{array}$ \\
\hline
\end{tabular}




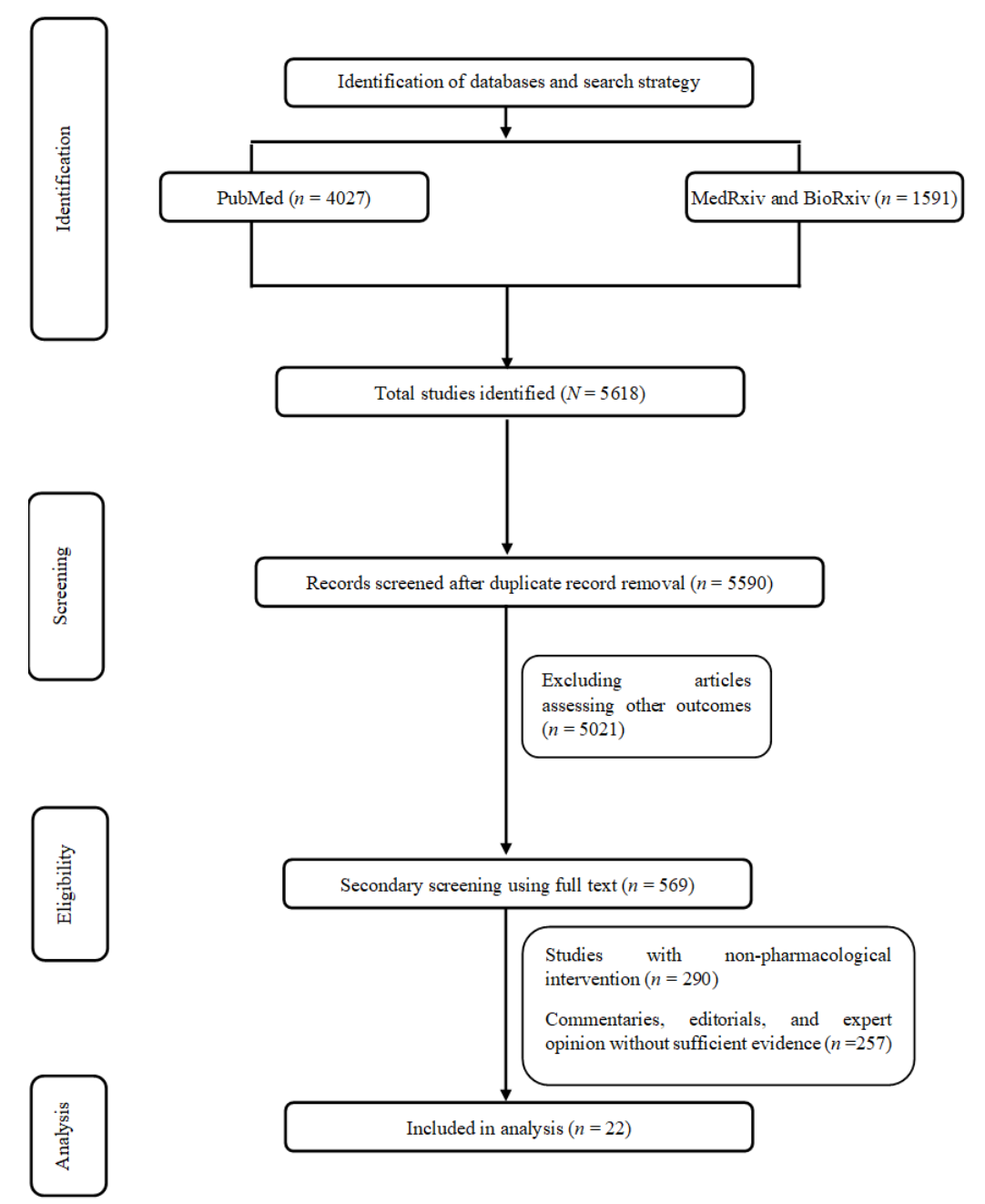

Figure 1

PRISMA study selection flowchart 